\title{
A Pragmatic Study of Junior High School Teachers' Speech Act of Criticism from the Perspective of Politeness Principle
}

\author{
Yuan-yuan Peng ${ }^{1}$ \\ ${ }^{1}$ Tourism Department of Leshan Vocational \& Technical College, China \\ Correspondence: Yuan-yuan Peng, Tourism Department of Leshan Vocational \& Technical College, Leshan, \\ Sichuan, China
}

Received: February 12, 2020

Accepted: March 10, 2020

Online Published: March 11, 2020

doi: 10.5539/elt.v13n4p11

URL: https://doi.org/10.5539/elt.v13n4p11

\begin{abstract}
Recently, there are limited specific researches on the pragmatic strategies of teachers' criticism from the angle of the Politeness Principle, among which most of them argue that teachers should adopt appropriate politeness strategies when criticizing students. However, only a few researchers point out that Leech's Politeness Principle is "other" oriented and neglects "self," which is too absolute, ideal, and unsuitable in teacher and student relations. In this paper, the author illustrates the true nature of politeness in teacher-student relations is that teachers should pay attention to self, show politeness to the students, and consider the third party (parents). Finally, the writer illustrates some politeness strategies, including criticizing with a sense of humour, criticizing in vague language, adopting empathy and showing politeness to a third party to show appropriate politeness to the students to make the criticism effective. The purpose is to make some middle school teachers recognize how to criticize appropriately.
\end{abstract}

Keywords: teachers' indirect criticism, politeness, face-saving, effective

\section{Introduction}

It is known to all that the purpose of teachers' criticism is to point out the shortcomings, mistakes, or errors of students objectively to enable students to recognize their mistakes, correct them, and learn from them. Levinson(1987) pointed out that criticism is a face-threatening act that can damage the real face of the hearer. So does it in teacher-student relation. However, direct criticism easily hurts the self-esteem of students because most of them regard direct criticism as a personal attack, which would put them down or make them embarrassed, disappointed, or annoyed rather than a help, students become less motivated, tend to be offensive or dislike the teacher. While indirect criticism can reduce their face-threatening and would not hurt their self-esteem, therefore, it is more effective and acceptable. Therefore, in order to save the negative face of the students and reduce the harmful effects of the criticism to a minimum, teachers always criticize the students in a much more indirect way to make the criticism effective and easy to be accepted without arousing hostility.

Up till now, there are limited specific researches on the pragmatic strategies of teachers' criticism from the angle of Politeness Principle, among which most of them argue that teachers should adopt appropriate politeness strategies when criticizing students. However, only a few researchers point out that Leech's Politeness Principle is "other" oriented and neglects "self," which is too absolute, ideal, and unsuitable in teacher and student relations. In this paper, the author illustrates the true nature of politeness in teacher-student relations is that teachers should pay attention to self, show politeness to the students, and consider the third party (parents). Finally, the writer illustrates some politeness strategies, including criticizing with a sense of humor, criticizing in vague language, adopting empathy and showing politeness to a third party to show appropriate politeness to the students.

This study tries to investigate the following questions: Which kind of criticism is popular with middle school students, and why? How do teachers give appropriate criticism to make the criticism acceptable and useful, establish a harmonious relationship between students and teachers as well as improve teaching quality? There are some issues here: Why do teachers show politeness to students when criticizing? What does real politeness mean? How can a teacher criticize respectfully? 
In order to solve the problems, the author provides some suggestions as follows:

1) Middle school teachers should pay attention to their ways of criticizing.

2)Teachers should show appropriate politeness strategies to students, including criticizing with a sense of humor, in vague language, adopting empathy and considering parents.

Based on these suggestions, the author establishes the aims of the study as follows:

1) to gather sufficient data for statistical analysis and interpretation.

2) to make some middle school teachers recognize how to criticize correctly.

\section{Some Politeness Strategies in Teachers' Criticism}

According to Leech's Politeness Principle and Brown \& Levinson's FAT, the purpose of people intentionally violate the maxim under cooperative principle is to lessen the face-threatening to "self" or "other" and reduce the harmful effects of criticism into a minimum. However, both of them are too ideal and absolute, which are "other" oriented and neglects "self." The overemphasis on the hearer's face, which overlooks the appropriateness in language strategy. In the teacher and student relationship, overemphasis on students' faces would reduce their prestige and would be a face threaten to themselves. That would be a big problem in education if teachers reluctant to criticize the students making mistakes. Hence, the true nature of politeness in teacher and student relationship is that teachers should pay attention to themselves, show respect to the students, and consider parents (the third party). Moreover, to establish a harmonious relationship with students, make the suggestions or criticism easy to be accepted and improve the teaching quality, teachers should try to give the criticism in a houmous way, in vague language or adopt empathy while criticizing, the criticism can be more natural to be accepted and valid.

\subsection{Humour}

To handle the humor language properly will be not only amusing and thought-provoking, but also adjust the relationship, shorten the psychological distance, clear out the emotional barrier between the teacher and student. Most importantly, it is still good to build up the close, equal, and harmonious tie, making a tolerant, pleasant, and easy-to-get-along-with atmosphere between teaching and learning.

Example 1

The teacher was giving the class while a student was talking with the students around him. He did not pay attention to the class, his teacher criticized him humorously:

1) 某某同学的向心力实在太强, 磁性太吓人, 我们是不是需要为他消磁?

2) 某些同学头部偏转的角度已超过黄赤交角咯。

Teachers humorously implied that the students who were talking should pay more attention to the class, the houmous speeches above reduced the face-threatening to the students as well as attracting the students' attention in class and were easily accepted by the students.

Example 2

Some teachers reacted to the students sleeping in class, as follow:

1）老师讲得不好, 让有的学生产生了休眠现象, 老师要回去申请专利'专治失眠。

2) 是沉醉, 还是沉睡?

3) 娃娃, 今天的憼口水就是明天的眼流花花!

The sentences mentioned above not only followed the Politeness Principle but also tactfully conveyed the teachers' real intention, that is, to attract the students to attend and remove an unpleasant conflict with each other.

Example 3

A boy student showing great talent in playing chess was found playing Chinese chess in class again, the teacher uses the following utterances with a sense of humor to remind students not to play chess during class, or he may fail in the examination.

1) 上课哈, 你再这么整就是马踏斜日你要走歪路了。

2) 你娃娃棋艺还有待加强, 轻而易举就被我将了一军! 要想成为象棋高手, 还有待努力, 我看你还是先 下好课堂这一局吧。. 


\section{Example 4}

1) 你开的中药方老师确实看不懂, 我怕吃错了药。

2) 搞副业的同学赶快把工具收下去。不要让其他同学晓得了哈, 再说私活怎能公开干。

It can be seen from all these examples above that, humor is a powerful weapon when criticizing students. Teachers with a sense of humor cultivates a casual and humorous education ambiance, which is more attractive to the students. Moreover, since these teachers have a way to get along with students, it is much easier for their criticism to be accepted.

\subsection{Adaptation of Vague Language in Criticism}

Vagueness is considered to be a way of adhering to the politeness rules of a particular culture. Speakers may use vagueness to mitigate face threats. Criticism is a face-threatening act, it can save faces, maintain harmonious interpersonal relations, then achieve the communicative goal finally. Teachers can sometimes use "I am afraid, I think, I would, it seems that, perhaps, maybe in the assessment of the students' activities and their homework, which alleviates the nervous atmosphere and reduces the implied cost to the hearer. With the vague term, the request costs less, and it is more polite. For example:

1) I am afraid you may get the wrong method.

2) I would suggest that you should practice more after class.

\subsection{Adopting Empathy}

Teachers can adopt empathy in criticism to make their criticism more effective. Teachers should show interest in the students, and considerate students by seeing things from his or her perspective in a warm, considerate and friendly way, such a you-attitude helps to enhance the students' positive face, promote positive politeness, establish good teacher-student relationship, thus, it can facilitate and accelerate the communication between teachers and students. Empathy requires teachers to put students in mind when giving criticism, keep asking these questions:

"What the purpose of criticism?"

"What would be my feelings if I were criticized?"

"What will be the most likely students' reaction to the criticism given by me?"

"How can I criticize the students in a most effective, clear, and polite way?"

\subsection{Politeness to A Third Party}

According to Leech (1983), the Politeness Principle is also observed in an other-oriented way, it minimizes cost to "other" and maximizes cost to "self," no matter whether the third party belongs to "other" or "self" or the third party is just neutral. In the teacher-student relationship, the third party usually refers to the parents, teachers should respect parents, treat them whole-heatedly and equally.

The headteacher criticizes the parents whose child gets deficient scores. Most of the parents felt sick and annoyed at once, for their faces were threatened. However, they could do nothing but scolded their children.

From the examples above, it can be seen that indirectness in wording functions in teachers' criticism when a third party is involved in the 'face-work'. Generally speaking, the more indirect, the less face-threatening. However, to maintain relationships or to make the teachers' criticism to be readily accepted and practical, the face-threatening to the third party should be reduced as much as possible.

\section{Conclusion}

Indirectness is a mean of showing politeness to students, lessening the face-threatening to "self" or "other" and reducing the harmful effects of criticism into a minimum, teachers should show appropriate politeness to students, including criticizing with a sense of humor, in vague language, adopting empathy, and considering the third party.

\section{References}

Channell, J. (1994). Vague Language. Oxford: Oxford University Press.

George Yule. (2003). Pragmatics. Shanghai Foreign Language Teaching and Research Press.

Grice, H.P. (1975). Logic, and conversation. New
https://doi.org/10.1163/9789004368811_003 
Leech, G.N. (1983). Principles of Pragmatics. London: Longman.

Yan Huang.Pragmatics. (2007). Foreign Language Teaching and Research Press, Cambridge University Press.

Wang Huiping. (2005). A Critical Study of Mr. Gu Yueguo's Politeness Maxims. An Hui University.

Zhu Xiangyan. (2002). Study on the Speech Act of Chinese Criticism and It's Guidance to Chinese Teaching for Foreigners. Ji Nan University.

\section{Copyrights}

Copyright for this article is retained by the author(s), with first publication rights granted to the journal.

This is an open-access article distributed under the terms and conditions of the Creative Commons Attribution license (http://creativecommons.org/licenses/by/4.0/). 